\title{
Chemical Composition and Anti-Inflammatory Effect of Ethanolic Extract of Brazilian Green Propolis on Activated J774A.1 Macrophages
}

\author{
Ewelina Szliszka, ${ }^{1}$ Alicja Z. Kucharska, ${ }^{2}$ Anna Sokół-Lętowska, ${ }^{2}$ Anna Mertas, ${ }^{1}$ \\ Zenon P. Czuba, ${ }^{1}$ and Wojciech Król ${ }^{1}$ \\ ${ }^{1}$ Department of Microbiology and Immunology, Medical University of Silesia in Katowice, Jordana 19, 41808 Zabrze, Poland \\ ${ }^{2}$ Department of Fruit and Vegetables and Cereals Technology, Wrocław University of Environmental and Life Sciences, \\ Chetmońskiego 37/41, 51630 Wrocław, Poland \\ Correspondence should be addressed to Wojciech Król; wkrol@sum.edu.pl
}

Received 4 April 2013; Accepted 8 May 2013

Academic Editor: Andrzej K. Kuropatnicki

Copyright (c) 2013 Ewelina Szliszka et al. This is an open access article distributed under the Creative Commons Attribution License, which permits unrestricted use, distribution, and reproduction in any medium, provided the original work is properly cited.

\begin{abstract}
The aim of this study was to investigate the chemical composition and anti-inflammatory effect of ethanolic extract of Brazilian green propolis (EEP-B) on LPS + IFN- $\gamma$ or PMA stimulated J774A.1 macrophages. The identification and quantification of phenolic compounds in green propolis extract were performed using HPLC-DAD and UPLC-Q-TOF-MS methods. The cell viability was evaluated by MTT and LDH assays. The radical scavenging ability was determined using $\mathrm{DPPH}^{*}$ and $\mathrm{ABTS}^{\circ+}$. ROS and RNS generation was analyzed by chemiluminescence. NO concentration was detected by the Griess reaction. The release of various cytokines by activated J774A.1 cells was measured in the culture supernatants using a multiplex bead array system based on xMAP technology. Artepillin C, kaempferide, and their derivatives were the main phenolics found in green propolis. At the tested concentrations, the EEP-B did not decrease the cell viability and did not cause the cytotoxicity. EEP-B exerted strong antioxidant activity and significantly inhibited the production of ROS, RNS, NO, cytokine IL- $1 \alpha$, IL-1 $\beta$, IL- 4 , IL-6, IL-12p 40 , IL- 13 , TNF- $\alpha$, G-CSF, GM-CSF, MCP-1, MIP-1 $\alpha$, MIP-1 $\beta$, and RANTES in stimulated J774A.1 macrophages. Our findings provide new insights for understanding the anti-inflammatory mechanism of action of Brazilian green propolis extract and support its application in complementary and alternative medicine.
\end{abstract}

\section{Introduction}

Propolis is a resinous substance collected by honeybees from the leaf bud and bark of certain plants. Baccharis dracunculifolia, Eucalyptus citriodora, Araucaria angustifolia, and Myrocarpus frondosus are major botanical sources of propolis from southeast Brazil (States of Minas Gerais and Sao Paulo) called due to its colour green propolis $[1,2]$. Extracts of Brazilian green propolis possess antioxidant, antimicrobial, anti-inflammatory, chemopreventive, and anticancer properties [3-9]. Therefore, propolis has been extensively used in food, beverages, and dietary supplements to improve health and prevent diabetes, cancer, inflammatory, and heart diseases [10-13]. The medical application of propolis has led to increased interest in its chemical composition depending on the geographical origin and specific flora of the region, seasonality or methods of harvesting the raw material [1-4].

Our study was designed to investigate the chemical composition and anti-inflammatory effect of ethanolic extract of Brazilian green propolis (EEP-B) on LPS (lipopolysaccharide) + IFN- $\gamma$ (interferon $\gamma$ ) or PMA (phorbol 12-myristate 13-acetate) stimulated J774A.1 macrophages.

Macrophages are the first effector cells of the immune system that protect against microbial infection and tissues injury. Macrophages have three important functions: antigen presentation, phagocytosis, and synthesis of various inflammatory mediators $[14,15]$. Propolis affects the nonspecific immunity via modulation of macrophages activity [3, 13]. During inflammation, upon stimulation by LPS from Gram-negative bacteria and IFN- $\gamma$ from host immune cells, 
macrophages release large amounts of reactive oxygen (ROS) and nitrogen species (RNS), nitric oxide (NO), and numerous cytokines [16]. Overexpression of these mediators causes pathological, acute, or chronic inflammatory responses [14].

This is the first comprehensive report explaining an antiinflammatory potential of Brazilian green propolis extract on macrophage in vitro model. We determined the effect of EEP-B on production of NO, ROS, RNS, and cytokines: interleukin (IL)-IL- $\alpha$, IL-1 $\beta$, IL-3, IL-4, IL-5, IL-6, IL-9, IL-10, IL-12p40, IL-13, IL-17, TNF- $\alpha$ (tumor necrosis factor $\alpha$ ), IFN- $\gamma$ (interferon $\gamma$ ), G-CSF (granulocyte colony-stimulating factor), GM-CSF (granulocyte-macrophage colonystimulating factor), MCP-1 (monocyte chemotactic protein 1), MIP- $1 \alpha$ (macrophage inflammatory protein $1 \alpha$ ), MIP-1 $\beta$ (macrophage inflammatory protein $1 \beta$ ), and RANTES (regulated upon activation normal $\mathrm{T}$ cell expressed and secreted) in activated J774A.1 cells.

It has been suggested that the immunomodulatory properties of propolis is contributed by its flavonoids and phenolic acids $[3,5,9,17]$. The typical ingredients of Brazilian green propolis are kaempferide (3,5,7-trihydroxy-4 ${ }^{\prime}$-methoxyflavone) and cinnamic acid derivatives: $p$-coumaric acid (4hydroxycinnamic acid), artepillin C (3,5-diprenyl-4-hydroxycinnamic acid), baccharin (3-prenyl-4-(dihydrocinnamoyloxy)-cinnamic acid) and drupanin (3-prenyl-4-hydroxycinnamic acid) $[1,4,18]$. We performed the detailed identification and quantification of phenolic compounds in propolis extract.

The present study analyzed chemical composition of green propolis and confirmed its significant role in suppressing chronic inflammation and reducing risk of related human health problems. Our findings provide new insights for understanding the anti-inflammatory mechanism of action of Brazilian green propolis extract and support its application in complementary and alternative therapies.

\section{Materials and Methods}

2.1. General. The Brazilian green propolis sample was kindly supplied by Nihon Natural Foods Co., Ltd. (Tokyo, Japan). LPS (LPS E. coli O111:B4) was obtained from Fluka Chemie $\mathrm{GmbH}$ (Buchs, Switzerland) and recombinant mouse IFN$\gamma$ was purchased from R\&D Systems (Minneapolis, MN, USA). PMA, DMSO (dimethyl sulphoxide), acetonitrile, and formic acid were obtained from Sigma-Aldrich (Steinheim, Germany). Acetonitrile for LC-MS was purchased from POCh (Gliwice, Poland). The following compounds were used as standards: sakuranetin, hesperitin, caffeic acid (Roth, Karlsruhe, Germany), kaempferol, pinocembrin, naringenin, p-coumaric acid (Sigma-Aldrich, Steinheim, Germany), kaempferide, ferulic acid (Serva, Heidelberg, Germany), isosakuranetin (TransMIT GmbH, Giessen, Germany), and artepillin C (Wako Pure Chemicals, Osaka, Japan).

2.2. Preparation of Brazilian Green Propolis Extract. The Brazilian green propolis sample was collected manually from beehive located in southeast Brazil (the state of Minas Gerais) and was kept desiccated prior to processing. The sample was extracted in $95 \% \mathrm{v} / \mathrm{v}$ ethyl alcohol, in a hermetically sealed glass vessel for 4 days at $37^{\circ} \mathrm{C}$, under occasional shaking. The ethanolic extract of Brazilian green propolis (EEP-B) was then filtered through Whatman filter paper no. 4 and evaporated in a rotary evaporator, under reduced pressure at $60^{\circ} \mathrm{C}$. The same collection and extraction procedures were used throughout all our laboratory studies $[6,12]$. EEP-B was dissolved in DMSO $(50 \mathrm{mg} / \mathrm{mL})$, and the final concentration of DMSO in the culture medium was controlled at $0.1 \%(\mathrm{v} / \mathrm{v})$.

\subsection{Identification and Quantification of Phenolic Compounds} by HPLC-DAD Method. Phenolic compounds were determined using Dionex (USA) HPLC system equipped with diode array detector model Ultimate 3000, a quaternary pump LPG-3400A, autosampler EWPS-3000SI, and thermostated column compartment TCC-3000SD and controlled by Chromeleon v.6.8 software. The reversed phase Cadenza 5CD-C18 $(75 \mathrm{~mm} \times 4.6$ i.d.) column (Imtakt, Kyoto, Japan) with guard column Cadenza $(5 \times 4.6$ i.d. $)$ guard column (Imtakt, Kyoto, Japan) was used. The mobile phase was composed of (A) $0.1 \%(\mathrm{v} / \mathrm{v})$ formic acid in water and (B) acetonitrile. The applied elution conditions were 0 min $20 \%$ B; $0-10$ min linear gradient from $20 \%$ to $30 \% \mathrm{~B} ; 10-40 \mathrm{~min}$ linear gradient from $30 \%$ to $40 \% \mathrm{~B} ; 40-60 \mathrm{~min}$, linear gradient from $40 \%$ to $60 \% \mathrm{~B} ; 60-80 \mathrm{~min}$, linear gradient from $60 \%$ to $80 \% \mathrm{~B}$; and then again the initial conditions [19-23]. The flow rate was $1 \mathrm{~mL} / \mathrm{min}$, and the injection volume was $20 \mu \mathrm{L}$. The column was operated at $30^{\circ} \mathrm{C}$. The compounds were monitored at $290 \mathrm{~nm}, 325 \mathrm{~nm}$, and $370 \mathrm{~nm}$.

\subsection{Identification and Quantification of Phenolic Compounds} by LC-MS Method. Compounds identification was performed on an Acquity ultra-performance liquid chromatography (UPLC) system coupled with a quadruple time of flight (Q-TOF) MS instrument (UPLC/Synapt Q-TOF MS, Waters Corp., Milford, MA, USA) with an electrospray ionization (ESI) source. Separation was achieved on the Acquity BEH C18 column $(100 \mathrm{~mm} \times 2.1 \mathrm{~mm}$ i.d., $1.7 \mu \mathrm{m}$; Waters $)$. Detection wavelengths were set at 290, 325, and $370 \mathrm{~nm}$. A mobile phase was a mixture of $1.5 \%$ formic acid (A) and acetonitrile (B). The gradient program was as follows: initial conditions95\% (A), 12 min-5\% (A), 13 min-5\% (A), 14.5 min-95\% (A), and $16 \mathrm{~min}-95 \%(\mathrm{~A})$. The flow rate was $0.45 \mathrm{~mL} / \mathrm{min}$ and the injection volume was $5 \mu \mathrm{L}$. The column was operated at $30^{\circ} \mathrm{C}$. The major operating parameters for the Q-TOF MS were set as follows: capillary voltage $2.0 \mathrm{kV}$, cone voltage $45 \mathrm{~V}$, cone gas flow of $11 \mathrm{~L} / \mathrm{h}$, collision energy $50 \mathrm{eV}$, source temperature $100^{\circ} \mathrm{C}$, desolvation temperature $250^{\circ} \mathrm{C}$, collision gas, argon; desolvation gas (nitrogen) flow rate, $600 \mathrm{~L} / \mathrm{h}$; data acquisition range, $m / z$ 100-1.000 Da; ionization mode, negative [24-26]. The data were collected by Mass-Lynx V 4.1 software.

2.5. Cell Culture. Murine macrophage J774A.1 cell line was obtained from ATCC (American Type Culture Collection, Manassas, VA, USA). Cells were cultured in Dulbecco's modified Eagle's medium supplemented with 10\% heatinactivated fetal bovine serum, $100 \mathrm{U} / \mathrm{mL}$ penicillin, and $100 \mu \mathrm{g} / \mathrm{mL}$ streptomycin at $37^{\circ} \mathrm{C}$ and $10 \% \mathrm{CO}_{2}$ in a humidified 
incubator [27]. Reagents for cell culture were purchased from ATCC. J774A.1 cells were seeded at a density of $1 \times 10^{6} / \mathrm{mL}$ cells $\left(2 \times 10^{5} /\right.$ well $)$ in 96 -well plates at the presence of LPS $(200 \mathrm{ng} / \mathrm{mL})$ and IFN- $\gamma(25 \mathrm{U} / \mathrm{mL})$ with or without EEP-B for $24 \mathrm{~h}$.

2.6. Cell Viability Assay. The cell viability was determined by the 3-(4,5-dimethyl-2-thiazyl)-2,5-diphenyl-2H-tetrazolium bromide (MTT) reduction assay as described $[28,29]$. This test is based on the cleavage of the tetrazolium salt MTT to a blue formazan dye by viable cells. The J774A.1 cells $(1 \times$ $10^{6} / \mathrm{mL}$ ) were seeded $4 \mathrm{~h}$ before the experiments in a 96well plate. EEP-B at the concentrations of $5-50 \mu \mathrm{g} / \mathrm{mL}$ with or without LPS + IFN- $\gamma$ was added to the cells. The final volume was $200 \mu \mathrm{L}$. After $24 \mathrm{~h}$ the medium was removed and $20 \mu \mathrm{L}$ MTT solutions $(5 \mathrm{mg} / \mathrm{mL}$ ) (Sigma Chemical Company, St. Louis, MO, USA) were added to each well for $4 \mathrm{~h}$. The resulting formazan crystals were dissolved in DMSO. The controls included native cells and medium alone. The spectrophotometric absorbance was measured at $550 \mathrm{~nm}$ wavelength using a microplate reader (ELx 800, Bio-Tek Instruments Inc., Winooski, VT, USA). The cytotoxicity as percentage of cell death was calculated by the formula: (1 - [absorbance of experimental wells/absorbance of control wells]) $\times 100 \%$.

2.7. Cytotoxicity Assay. The cytotoxicity of EEP-B was determined by using LDH activity assay kit (Roche Diagnostics $\mathrm{GmbH}$, Mannheim, Germany) [30, 31]. Lactate dehydrogenase (LDH) is a stable cytosolic enzyme released upon membrane damage in necrotic cells. The J774A.1 $\left(1 \times 10^{6} / \mathrm{mL}\right)$ cells were treated with $5-50 \mu \mathrm{g} / \mathrm{mL}$ EEP-B with or without LPS + IFN- $\gamma$ for the indicated period of time. LDH released in culture supernatants is detected with coupled enzymatic assay, resulting in the conversion of a tetrazolium salt into a red formazan product. The maximal release of LDH was obtained after treating control cells with $1 \%$ Triton X-100 (Sigma Chemical Company, St. Louis, MO) for $10 \mathrm{~min}$ at room temperature. The spectrophotometric absorbance was measured at $490 \mathrm{~nm}$ wavelength using a microplate reader (ELx 800, Bio-Tek Instruments Inc., Winooski, VT, USA). The percentage of necrotic cells was expressed using the following formula: (sample value/maximal release) $\times 100 \%$.

2.8. DPPH Radical Scavenging Activity. Hydrogen-donating activity was measured using 1,1-diphenyl-2-picrylhydrazyl radical $\left(\mathrm{DPPH}^{*}\right)$ (Sigma Chemical Company, St. Louis, $\left.\mathrm{MO}\right)$ following a previously reported protocol [32]. EEP-B $(0.1 \mathrm{~mL})$ was mixed with $0.9 \mathrm{~mL}$ of $0.041 \mathrm{mM} \mathrm{DPPH}^{\circ}$ in ethanol and stored at room temperature in the dark for $30 \mathrm{~min}$. The absorbance of the resulting solutions was measured at $517 \mathrm{~nm}$ wavelength using V-630 Spectrophotometer (Jasko International Co., Tokyo, Japan). The percentage of scavenging activity was calculated by the formula: $\mathrm{DPPH}^{*}$ scavenging activity $=1-$ (absorbance of experimental wells/absorbance of control wells) $\times 100 \%$. The scavenging activity of the sample was expressed as the $\mathrm{ED}_{50}$ value, the concentration required to scavenge $50 \%$ of $\mathrm{DPPH}^{\circ}$. Ascorbic acid was used as a standard.

2.9. ABTS Cation Radical Scavenging Activity. 2,2'-Azinobis(3-ethylbenzothiazoline-6-sulfonic acid) radical cation $\left(\mathrm{ABTS}^{*+}\right.$ ) (Sigma Chemical Company, St. Louis, MO) scavenging activity was determined according to the previously described procedure [32]. EEP-B $(0.1 \mathrm{~mL})$ was mixed with potassium phosphate buffer $(0.1 \mathrm{~mL}$ of $0.1 \mathrm{M})$ and hydrogen peroxide $(10 \mu \mathrm{L}$ of $10 \mathrm{mM})$ and preincubated at $37^{\circ} \mathrm{C}$ in the dark for $5 \mathrm{~min}$. Next, ABTS $(30 \mu \mathrm{L}$ of $1.25 \mathrm{mM}$ in $0.05 \mathrm{M}$ phosphate-citrate buffer) and peroxidase ( $30 \mu \mathrm{L}$ of $1 \mathrm{unit} / \mathrm{mL})$ were added to the mixture and then incubated at $37^{\circ} \mathrm{C}$ in the dark for $10 \mathrm{~min}$. The absorbance of the resulting solutions was measured at $417 \mathrm{~nm}$ wavelength using V-630 Spectrophotometer (Jasko International Co., Tokyo, Japan). The percentage of scavenging activity was calculated by the formula: $\mathrm{ABTS}^{\circ+}$ scavenging activity $=1-$ (absorbance of experimental well/absorbance of control wells) $\times 100 \%$. The scavenging activity of the sample was expressed as the $\mathrm{ED}_{50}$ value, the concentration required to scavenge $50 \%$ of $\mathrm{ABTS}^{\circ+}$. Ascorbic acid was used as a standard.

2.10. Detection of ROS and RNS Production by Chemiluminescence. The chemiluminescence of J774A.1 macrophages was evaluated by microplate method in Hank's balanced salt solution, $\mathrm{pH} 7.4$, at room temperature. The cells were incubated with $0.01-10 \mu \mathrm{g} / \mathrm{mL}$ EEP-B for $30 \mathrm{~min}$. Next, luminol (Sigma Chemical Company, St. Louis, MO, USA) solution was added to wells containing $2 \times 10^{5}$ cells, giving a final concentration of $110 \mu \mathrm{M}$. After $5 \mathrm{~min}$, for macrophages stimulation PMA solution was injected to obtain the concentration of $0.8 \mu \mathrm{M}$. The final volume of each sample was $200 \mu \mathrm{L}$. The chemiluminescence was determined for $5 \mathrm{~min}$ with luminol alone and after stimulation with PMA for $30 \mathrm{~min}$. The measuring system was equipped with LB 960 CentroXS $^{3}$ microplate luminometer (Berthold Technologies GmbH, Wildbad, Germany) [33].

2.11. Quantification of NO Production. J774A.1 macrophages $\left(1 \times 10^{6} / \mathrm{mL}\right)$ stimulated with LPS + IFN- $\gamma$ were incubated with $5-50 \mu \mathrm{g} / \mathrm{mL}$ EEP-B for $24 \mathrm{~h}$. After this time NO production was determined by measuring the accumulation of nitrite, a stable end product, in the culture supernatant according to the Griess reaction [27, 34]. Equal volumes of culture supernatant from each well or medium $(100 \mu \mathrm{L})$ were mixed with $100 \mu \mathrm{L}$ of Griess reagent in a 96-well plate and incubated for $15 \mathrm{~min}$ at room temperature. The spectrophotometric absorbance was read at $550 \mathrm{~nm}$ wavelength in Eon Microplate Spectrophotometer (BioTek, Winooski, VT, USA) and the nitrite concentration in the medium was calculated using sodium nitrite as a standard. Nitrite was not detectable in cell-free medium.

2.12. Multiplex Bead-Based Cytokine Assay. Cytokines released from J774A.1 macrophages treated with EEP-B were determined in the cell culture supernatants with a Pro Mouse Cytokines 19-plex assay kit for IL-1 $\alpha$, IL-1 $\beta$, IL-3, IL-4, IL5, IL-6, IL-9, IL-10, IL-12p40, IL-13, IL-17, TNF- $\alpha$, IFN- $\gamma$, 
G-CSF, GM-CSF, MCP-1, MIP- $1 \alpha$, MIP- $1 \beta$, and RANTES (Bio-Rad Laboratories Inc., Hercules, CA, USA). This test was performed using Bio-Plex 200 System based on xMAP suspension array technology (Bio-Rad Laboratories Inc., Hercules, CA, USA). The LPS + IFN- $\gamma$ stimulated and native J774A. 1 cells $\left(1 \times 10^{6} / \mathrm{mL}\right)$ were incubated with or without $25-$ $50 \mu \mathrm{g} / \mathrm{mL}$ EEP-B for $24 \mathrm{~h}$. Standard curves for each cytokine were generated using kit-supplied reference cytokine sample. The assay is designed for the multiplexed quantitative measurement of multiple cytokines in a single well using $50 \mu \mathrm{L}$ of sample. Briefly, the following procedure was performed: after prewetting the 96-well filter plate with washing buffer, the solution in each well was aspirated using a vacuum manifold. Next, the cell culture supernatants were incubated with antibody-conjugated beads for $30 \mathrm{~min}$. Following the incubational period, detection antibodies and streptavidin$\mathrm{PE}$ were added to each well for $30 \mathrm{~min}$. Then, after washing with buffer to remove the unbound streptavidin-PE, the beads bound to each cytokine were analyzed in the Bioplex Array Reader (Bio-Plex 200 System). The fluorescence intensity was evaluated using Bio-Plex Manager software (Bio-Rad) [33, 35].

2.13. The Statistical Analysis. The values represent mean \pm SD of two, three, or four independent experiments performed in duplicate or quadruplicate. Significant differences were analyzed using Student's $t$-test and $P$-values $<0.05$ were considered significant. The concentration-response curves were analyzed using Pharma/PCS version 4 (Pharmacological Calculations System) software.

\section{Results}

3.1. The Content and Characterization of Phenolic Compounds Identified in Brazilian Green Propolis Extract. The identification and quantification of phenolic compounds in Brazilian green propolis extract were performed using HPLC-DAD and UPLC-Q-TOF-MS methods. Qualitative analysis results obtained by LC-ESI/MS methods and quantitative analysis data obtained by HPLC (quantified using DAD detection) are presented in Figures 1, 2, 3, and 4 and Table 1. A total of fortythree phenolic ingredients were found in tested propolis sample. Thirty-four compounds were identified by comparison of their UV and MS/MS spectra to standards and/or to the literature data, whereas another nine compounds remained unknown. Kaempferide, with its derivatives, and hesperitin, which were characterized by MS from their molecular ions at $m / z 299.0572$ and 301.0709, respectively, are the major flavonoids identified in Brazilian green propolis. Among the phenolic acids, prevailed $p$-coumaric acid $(\mathrm{m} / z 163.0406$ and fragment at $m / z 119$ resulting from the loss of a COO group) and prenylated cinnamic acid derivatives: artepillin C $(m / z 299.1634)$, baccharin $(m / z$ 363.1619), and drupanin ( $m / z$ 231.1025) (Table 1).

3.2. Effect of Brazilian Green Propolis Extract on Viability of J774A.1 Macrophages. The cell viability in the presence of 5$50 \mu \mathrm{g} / \mathrm{mL}$ EEP-B and/or LPS + IFN- $\gamma$ for $24 \mathrm{~h}$ was measured by MTT test (Figure 5). The cytotoxicity of the propolis extract at the same concentrations and incubation time was evaluated by LDH assay. EEP-B at the concentrations of $\leq 50 \mu \mathrm{g} / \mathrm{mL}$ did not influence the cell viability and did not exert cytotoxic effect. Therefore for further studies of antiinflammatory properties EEP-B was used at the concentrations of $5-50 \mu \mathrm{g} / \mathrm{mL}$.

3.3. Antioxidant Activity of Brazilian Green Propolis Extract. Antioxidant activity of EEP-B was investigated by using two different methods for stable $\mathrm{DPPH}^{\bullet}$ and $\mathrm{ABTS}^{\bullet+}$. The propolis extract exhibited strong scavenging potential against $\mathrm{DPPH}^{\bullet}$ $\left(\mathrm{ED}_{50}\right.$ of $\left.24.1 \mu \mathrm{g} / \mathrm{mL}\right)$ and $\mathrm{ABTS}^{\circ+}\left(\mathrm{ED}_{50}\right.$ of $\left.40.6 \mu \mathrm{g} / \mathrm{mL}\right) \mathrm{com}-$ pared with ascorbic acid $\left(\mathrm{ED}_{50}\right.$ of $15.8 \mu \mathrm{g} / \mathrm{mL}$ and $10.1 \mu \mathrm{g} / \mathrm{mL}$, resp.).

\subsection{Effect of Brazilian Green Propolis Extract on ROS and RNS} Production in PMA Stimulated J774A.1 Cells. Changes in production of ROS and RNS in macrophages were determined by chemiluminescence assay. EEP-B at the concentrations of 0.01-10 $\mu \mathrm{g} / \mathrm{mL}$ suppressed the chemiluminescence in PMA stimulated J774A.1 cells in dose-dependent manner with an $\mathrm{ED}_{50}$ of $0.02 \mu \mathrm{g} / \mathrm{mL}$ (Figure 6).

\subsection{Effect of Brazilian Green Propolis Extract on NO Produc-} tion in LPS + IFN- $\gamma$ Stimulated J774A.1 Cells. NO production was determined by measuring the accumulation of nitrite in the culture supernatants using Griess reagent. After $24 \mathrm{~h}$ LPS + IFN- $\gamma$ stimulation nitrite concentration markedly increased, but LPS + IFN- $\gamma$-induced NO synthesis in J774A.1 cells was significantly decreased by EEP-B in dose-dependent manner $\left(\mathrm{ED}_{50}=30.1 \mu \mathrm{g} / \mathrm{mL}\right)$. The inhibitory effect of 5$50 \mu \mathrm{g} / \mathrm{mL}$ EEP-B on NO production in LPS + IFN- $\gamma$ stimulated macrophages is presented in Figure 7. The propolis extract did not interfere with the viability of J774A.1 cells, as shown in MTT and $\mathrm{LDH}$ test. The $\mathrm{ED}_{50}$ value of the EEP$\mathrm{B}$ within the nontoxic concentration range suggests that the inhibition of nitrite accumulation was specific to responses by macrophages (due to inhibitory activity on NO production and not cytotoxic property of EEP-B).

3.6. Effect of Brazilian Green Propolis Extract on Cytokine Production in LPS + IFN- $\gamma$ Stimulated J774A.1 Cells. The effect of EEP-B on production of cytokine IL- $1 \alpha$, IL- $1 \beta$, IL-3, IL-4, IL-5, IL-6, IL-9, IL-10, IL-12p40, IL-13, IL-17, TNF- $\alpha$, IFN- $\gamma$, G-CSF, GM-CSF, MCP-1, MIP- $1 \alpha$, MIP- $1 \beta$, and RANTES in LPS + IFN- $\gamma$ stimulated J774A.1 cells is shown in Figure 8. Specifically, native and activated J774A.1 macrophages were treated with $25-50 \mu \mathrm{g} / \mathrm{mL}$ EEP-B for $24 \mathrm{~h}$. The cytokines released in culture supernatants were analyzed simultaneously by Bio-plex Suspension Array System. This assay is designed for the multiplexed quantitative measurement of cytokines (19-plex) in a single well using $50 \mu \mathrm{L}$ of sample. EEP-B significantly decreased synthesis of IL$1 \alpha$, IL-1 $\beta$, IL-4, IL-6, IL-12p40, IL-13, TNF- $\alpha$, G-CSF, GMCSF, MCP-1, MIP- $1 \alpha$, MIP-1 $\beta$, and RANTES in LPS + IFN- $\gamma$ 


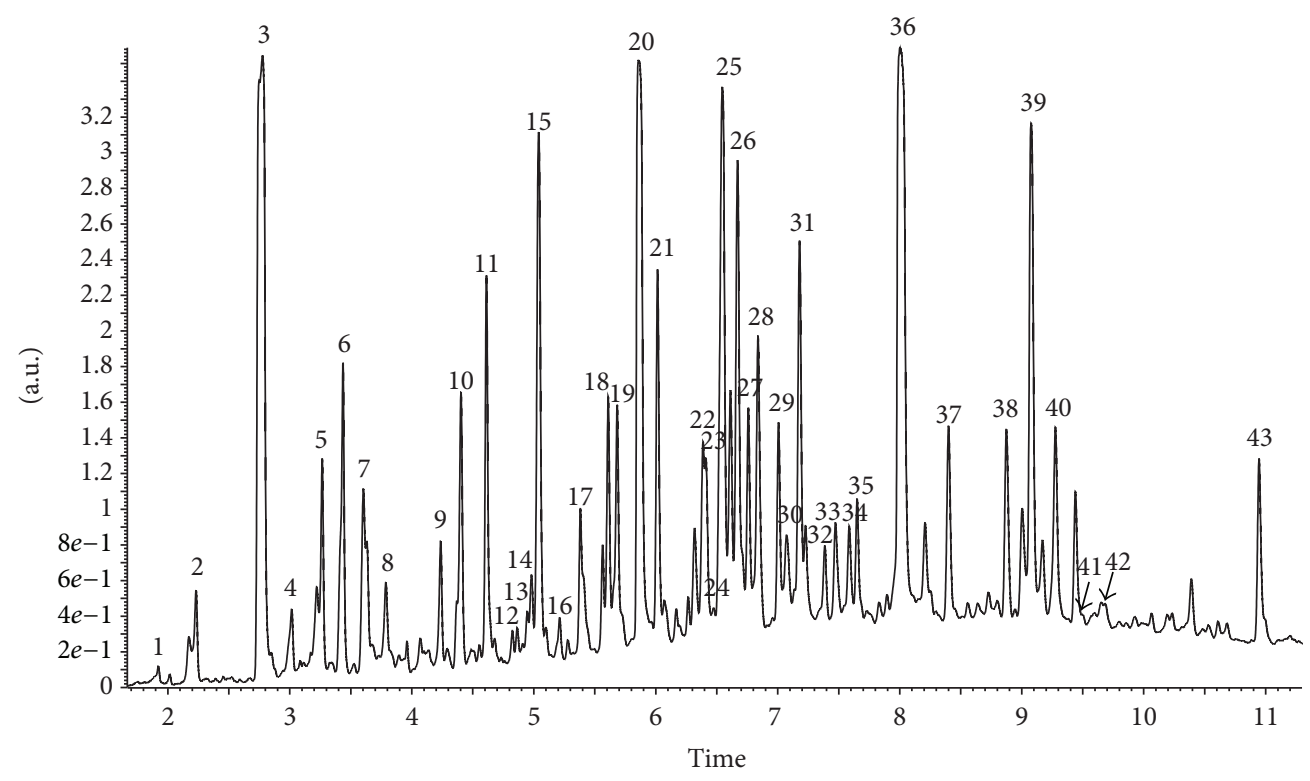

FIGURE 1: UPLC-DAD chromatogram $(290 \mathrm{~nm})$ of compounds of ethanol extract from Brazilian green propolis.



FIGURE 2: UPLC-DAD chromatogram $(325 \mathrm{~nm})$ of compounds of ethanol extract from Brazilian green propolis.

stimulated J774A.1 cells in dose-dependent manner. The EEPB did no influence the concentrations of IL-3, IL-5, IL-9, IL17 , and IFN- $\gamma$ and only slightly downregulates IL-10 in culture supernatants derived from activated macrophages.

\section{Discussion}

In Brazil, twelve distinct groups of propolis have been classified according to their botanical origin and biological properties. Green propolis collected in southern region of Brazil (States of Minas Gerais and Sao Paulo) belongs to Group 12 (propolis G12) [1]. Chemical evidence suggested that Baccharis dracunculifolia is the main plant source for green propolis [36]. Park et al. demonstrated similar profiles of phenolic components identified in green propolis extract and Baccharis dracunculifolia resins [37]. The tested sample of green propolis was rich in hesperitin, kaempferide and its derivatives, and cinnamic acid derivatives: $p$-coumaric acid, artepillin C, baccharin, and drupanin. Our studies confirmed the results obtained by Park et al. [1,37] and Banskota et al. [38].

Macrophages are the main cells responsible for innate (nonspecific) immunity. The J774A.1 cells, a murine macrophage cell line, are widely used to establish inflammatory model in vitro [27]. Numerous findings showed antioxidant and anti-inflammatory effects of propolis extract $[3,4,13$, $18,21,27,39,40]$. The biologically active molecules in green propolis are phenolic acids and flavonoids, which act as 


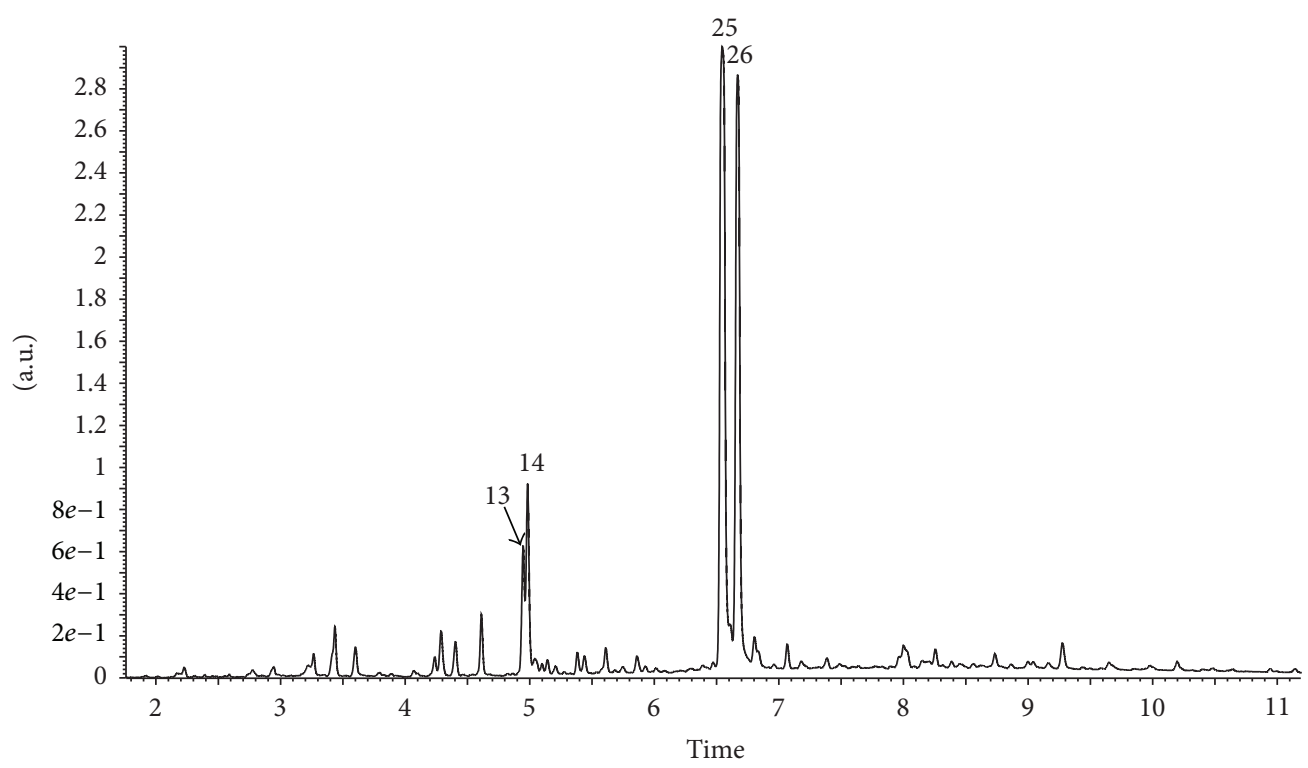

FIGURE 3: UPLC-DAD chromatogram $(370 \mathrm{~nm})$ of compounds of ethanol extract from Brazilian green propolis.



FIGURE 4: UPLC-ESI-MS (negative ion) chromatogram of main compounds of ethanol extract from Brazilian green propolis.

scavengers of free radicals and inhibitors of nitric oxide and inflammatory cytokines production by macrophages and/or neutrophils [4, 13, 16-18, 27, 34, 39, 40]. Kaempferide, artepillin $\mathrm{C}$, and their derivatives are the major constituents identified in our tested sample of Brazilian green propolis extract.

Brazilian green propolis exhibits significant antioxidant properties by scavenging ROS and inhibiting chemiluminescence reactions $[4,18,40]$. The topical or oral treatment of animals with Brazilian propolis extracts demonstrated potential effect against oxidative stress [41]. DPPH ${ }^{*}$ and $\mathrm{ABTS}^{\circ+}$ tests have been widely used for evaluating antioxidant properties of natural phenolic compounds. Antioxidants intercept the free radical chain oxidation by donating hydrogen from the phenolic hydroxyl groups, thereby forming stable end products, which do not initiate or propagate further oxidation. EEP-B exerted strong free radical scavenging activity based on reduction of $\mathrm{DPPH}^{\circ}$ and $\mathrm{ABTS}^{\circ+}[4,17]$. Izuta et al. showed the ability of scavenging $\mathrm{DPPH}^{*}$ by green propolis and artepillin $\mathrm{C}$, in contrast to other prenylated derivatives of cinnamic acid, drupanin and baccharin, which did not cause similar effect. The findings indicate that 3-prenyl chain of cinnamic acid is important for antioxidant activity of artepillin C [42]. Hayashi et al. noticed strong antioxidant effect of two compounds isolated from Brazilian propolis, kaempferide, and artepillin C [43]. In the present study we verified potent scavenging capability of EEP-B against $\mathrm{DPPH}{ }^{\circ}$ and $\mathrm{ABTS}^{++}$. 
TABLE 1: The content $[\mathrm{mg} / \mathrm{g}]$ and characterization of phenolic compounds of the ethanol extract of Brazilian green propolis using their spectral characteristic in negative ions in LC-ESI/MS.

\begin{tabular}{|c|c|c|c|c|c|}
\hline Peak & $\begin{array}{c}\text { Retention time } \\
t_{r} \\
(\mathrm{~min})\end{array}$ & {$[\mathrm{M}-\mathrm{H}]^{-}$} & MS/MS fragments & Compound name* & $\begin{array}{c}\text { Quantity } \\
{[\mathrm{mg} / \mathrm{g} \text { of propolis] }]^{* *}}\end{array}$ \\
\hline (1) & 1.96 & 353.0879 & 191.0553/173.0446/161.0241/135.0440 & $\begin{array}{l}\text { Caffeoylquinic acid } \\
\text { isomer }{ }^{\text {b,c }}\end{array}$ & $6.49^{\mathrm{e}}$ \\
\hline (2) & 2.26 & 179.0349 & $161.0241 / 135.0440$ & Caffeic acid ${ }^{\mathrm{a}}$ & 1.29 \\
\hline (3) & 2.79 & 163.0406 & 119.0510 & $p$-Coumaric acid ${ }^{\mathrm{a}}$ & 19.90 \\
\hline (4) & 3.02 & 193.0492 & 193.0492 & Ferulic acid ${ }^{a}$ & 1.48 \\
\hline (5) & 3.30 & 515.1196 & $353.0879 / 191.0553 / 179.0349 / 161 / 0241 / 135.0440$ & $\begin{array}{c}\text { Dicaffeoylquinic acid } \\
\text { izomer }^{\mathrm{b}, \mathrm{c}}\end{array}$ & $2.22^{\mathrm{e}}$ \\
\hline (6) & 3.46 & 515.1196 & $353.0879 / 191.0553 / 179.0349 / 161 / 0241 / 135.0441$ & $\begin{array}{c}\text { Dicaffeoylquinic acid } \\
\text { izomer }^{\mathrm{b}, \mathrm{c}}\end{array}$ & $2.55^{\mathrm{e}}$ \\
\hline (7) & 3.65 & 231.0652 & $187.0760 / 163.0380 / 145.0653$ & $\begin{array}{c}\text { Coumaric acid prenyl } \\
\text { ester }^{\mathrm{b}}\end{array}$ & $0.14^{\mathrm{d}}$ \\
\hline (8) & 3.84 & 487.1597 & 263.0911/179.0349/161.0241 & Caffeic acid derivative $^{c}$ & $0.55^{\mathrm{e}}$ \\
\hline (9) & 4.27 & 677.1512 & $515.1196 / 353.0879 / 191.0553 / 179.0349 / 161.0241 / 135.0441$ & Tricaffeoylquinic acid ${ }^{\mathrm{b}, \mathrm{c}}$ & $0.46^{\mathrm{e}}$ \\
\hline (10) & 4.43 & 543.1486 & $381.1173 / 179.0349 / 161.0241$ & $\begin{array}{c}\text { Dimethyl- } \\
\text { dicaffeoylquinic } \\
\text { acid }^{\mathrm{c}}\end{array}$ & $3.00^{\mathrm{e}}$ \\
\hline (11) & 4.65 & 543.1486 & $381.1173 / 179.0349 / 161.0241$ & $\begin{array}{c}\text { Dimethyl- } \\
\text { dicaffeoylquinic } \\
\text { acid }^{\mathrm{c}}\end{array}$ & $3.61^{\mathrm{e}}$ \\
\hline (12) & 4.89 & 271.0616 & $151.0017 / 133.0654 / 107.0134$ & Naringenin ${ }^{\mathrm{a}}$ & 0.54 \\
\hline (13) & 4.96 & 285.0394 & 285.0394 & Kempferol $^{\mathrm{a}}$ & 3.35 \\
\hline (14) & 5.01 & 315.0512 & $301.0709 / 151.0017$ & Isorhamnetin ${ }^{\mathrm{b}, \mathrm{c}}$ & $3.18^{\mathrm{h}}$ \\
\hline (15) & 5.08 & 301.0709 & $152.0119 /$ & Hesperitin $^{\mathrm{a}}$ & 8.42 \\
\hline (16) & 5.25 & 301.1455 & 239.1426/202.0992/132.0568 & $\mathrm{Ni}$ & - \\
\hline (17) & 5.43 & 705.1837 & $543.1486 / 381.1173 / 179.0349 / 161.0241$ & Caffeic acid derivative $^{c}$ & $0.83^{\mathrm{e}}$ \\
\hline (18) & 5.63 & 247.0982 & 203.1072/148.0535 & $\begin{array}{c}\text { 3,4-Dihydroxy } \\
\text { 5-prenylcinnamic acid }\end{array}$ & $2.41^{\mathrm{d}}$ \\
\hline (19) & 5.71 & 331.1565 & 331.1565 & $\mathrm{Ni}$ & $2.75^{\mathrm{d}}$ \\
\hline$(20)$ & 5.89 & 231.1025 & $187.1124 / 132.0568$ & $\begin{array}{l}\text { 4-Hydroxy } \\
\text { 3-prenylcinnamic acid } \\
{\text { (drupanin })^{\mathrm{b}}}^{\text {(drut }}\end{array}$ & $25.63^{\mathrm{d}}$ \\
\hline (21) & 6.05 & 315.1602 & $253.1609 / 201.1286 / 146.0728$ & $\begin{array}{l}\text { Coumaric acid } \\
\text { derivative }^{c}\end{array}$ & $3.61^{\mathrm{d}}$ \\
\hline$(22)$ & 6.44 & 285.0775 & $164.0171 / 119.0510$ & Sakuranetin $^{\mathrm{a}}$ & 2.43 \\
\hline (23) & 6.46 & 285.0775 & $164.0116 / 151.0042 / 135.0162 / 108.0215$ & Izosakuranetin $^{\mathrm{a}}$ & 3.39 \\
\hline$(24)$ & 6.51 & 255.0663 & $255.0663 /$ & Pinocembrin $^{\mathrm{a}}$ & 3.12 \\
\hline$(25)$ & 6.59 & 299.0572 & $284.0313 / 201.1286 / 151.0042$ & Kaempferide $^{\mathrm{a}}$ & 18.81 \\
\hline (26) & 6.72 & 377.1958 & $299.0572 / 201.1286$ & Kaempferide derivative $^{c}$ & $10.18^{\mathrm{g}}$ \\
\hline (27) & 6.78 & 393.1335 & $163.0380 / 145.0284 / 119.0510$ & Dicoumaric prenyl ester ${ }^{c}$ & $3.71^{\mathrm{d}}$ \\
\hline$(28)$ & 6.87 & 315.1602 & $299.0536 / 253.1609 / 198.1039$ & $\mathrm{Ni}$ & $4.16^{\mathrm{d}}$ \\
\hline (29) & 7.03 & 313.1433 & $211.1126 / 156.0583 / 149 / 0618$ & $\mathrm{Ni}$ & $0.61^{\mathrm{d}}$ \\
\hline$(30)$ & 7.10 & 529.1495 & $299.0572 / 284.0313$ & Kaempferide derivative $^{c}$ & $0.07^{\mathrm{g}}$ \\
\hline (31) & 7.22 & 315.1602 & $201.1286 / 146.0728$ & $\mathrm{Ni}$ & $0.06^{\mathrm{d}}$ \\
\hline (32) & 7.42 & 559.1631 & $329.0666 / 163.0380 / 145.0284 / 119.0488$ & $\begin{array}{c}\text { Coumaric acid } \\
\text { derivative }^{c}\end{array}$ & $0.42^{\mathrm{d}}$ \\
\hline (33) & 7.49 & 329.1780 & $299.1634 / 255.1742$ & Artepillin $\mathrm{C}$ derivative ${ }^{\mathrm{c}}$ & - \\
\hline
\end{tabular}


TABle 1: Continued.

\begin{tabular}{|c|c|c|c|c|c|}
\hline Peak & $\begin{array}{c}\text { Retention time } \\
t_{r} \\
(\mathrm{~min}) \\
\end{array}$ & {$[\mathrm{M}-\mathrm{H}]^{-}$} & MS/MS fragments & Compound name* & $\begin{array}{c}\text { Quantity } \\
{[\mathrm{mg} / \mathrm{g} \text { of propolis }]^{* *}}\end{array}$ \\
\hline (34) & 7.61 & 545.2541 & $331.1900 / 269.1174$ & $\mathrm{Ni}$ & - \\
\hline$(35)$ & 7.70 & 477.1917 & 211.1126/163.0380/145.0284/118.0415 & $\begin{array}{l}\text { Coumaric acid } \\
\text { derivative }\end{array}$ & $0.63^{\mathrm{d}}$ \\
\hline (36) & 8.06 & 299.1634 & $255.1742 / 200.1197$ & Artepillin $\mathrm{C}^{\mathrm{a}}$ & 51.44 \\
\hline$(37)$ & 8.40 & 585.1772 & $301.1455 / 125.0974$ & $\mathrm{Ni}$ & - \\
\hline (38) & 8.91 & 447.2171 & $297.1489 / 149.0613$ & $\mathrm{Ni}$ & - \\
\hline (39) & 9.13 & 363.1619 & $187.1124 / 149.0613 / 131.0497$ & $\begin{array}{l}\text { 3-Prenyl-4- } \\
\text { (dihydrocinnamoyloxy)- } \\
\text { cinnamic acid } \\
\text { (baccharin) }^{\mathrm{b}}\end{array}$ & $9.66^{\mathrm{d}}$ \\
\hline$(40)$ & 9.32 & 297.1489 & 253.1577/198.1039/152.9951 & $\mathrm{Ni}$ & $0.62^{\mathrm{d}}$ \\
\hline (41) & 9.51 & 321.2426 & $299.1634 / 255.1742$ & Artepillin derivative $^{c}$ & $0.89^{\mathrm{e}}$ \\
\hline$(42)$ & 9.77 & 321.2426 & $299.1634 / 255.1742$ & Artepillin derivative $^{c}$ & $2.99^{\mathrm{e}}$ \\
\hline$(43)$ & 10.99 & 613.3177 & 299.1634/281.1550/154.1682 & Artepillin derivative $^{c}$ & $1.41^{\mathrm{e}}$ \\
\hline
\end{tabular}

Ni: not identified.

${ }^{*, a}$ Confirmed by standard.

${ }^{\mathrm{b}}$ Confirmed by reference [19-21, 23, 24, 26].

${ }^{\mathrm{c}}$ Confirmed by MS fragmentation.

${ }^{* *, \mathrm{~d}}$ Expressed as $p$-coumaric acid.

${ }^{\mathrm{e}}$ Expressed as caffeic acid.

${ }^{\mathrm{f}}$ Expressed as artepillin C.

${ }^{g}$ Expressed as kaempferide.

${ }^{\mathrm{h}}$ Expressed as rhamnetin.

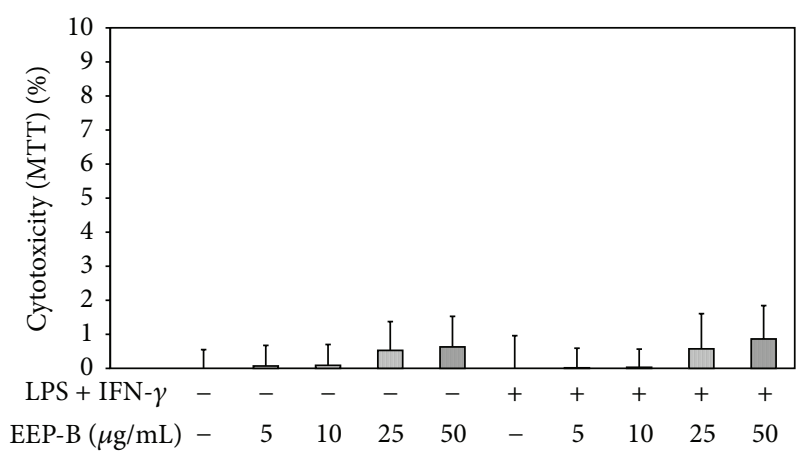

Figure 5: Effect of EEP-B on viability of J774A.1 macrophages. The cytotoxicity was evaluated by MTT assay after $24 \mathrm{~h}$ incubation of J774A.1 cells with $5-50 \mu \mathrm{g} / \mathrm{mL}$ EEP-B and/or LPS + IFN- $\gamma$. The values represent mean $\pm \mathrm{SD}$ of three independent experiments $(n=$ 12).

Regarding the anti-inflammatory property, the effect of EEP-B in ROS and RNS scavenging was also determined by chemiluminescence assay. We evaluated for the first time the role of green propolis in the oxidative metabolism of PMA stimulated macrophages. The ROS and RNS release by activated J774A.1 cells was significantly inhibited by EEP$\mathrm{B}$ in dose-dependent manner. Król et al. and Simões et al. proved that kaempferide and extracts of Polish and Brazilian green propolis decrease the chemiluminescence produced by stimulated neutrophils $[18,39,40]$.

$\mathrm{NO}$, a short half-life free radical, is an effector molecule in host defense against pathogens. NO production in macrophages is mediated by the inducible nitric oxide synthase (iNOS). However, excessive release of $\mathrm{NO}$ induced by LPS, IFN- $\gamma$, or TNF- $\alpha$ has detrimental effects on many organ systems of the body, leading to acute or chronic inflammatory diseases [44]. Song et al. reported that treatment of RAW264.7 cells with extract of Korean propolis markedly suppresses NO production and iNOS mRNA and protein expression induced by LPS + IFN- $\gamma$ [45]. Blonska et al. observed the inhibition of NO synthesis and iNOS mRNA expression in LPS stimulated J774A.1 macrophages by extract of Polish propolis and its phenolic components: chrysin, galangin, kaempferol, and quercetin [27]. Paulino et al. demonstrated that artepillin $\mathrm{C}$ decreases NO concentration in RAW264.7 cells incubated with LPS [46]. Król et al. described downregulation of NO by kaempferide in activated murine peritoneal macrophages [16]. Similar to previous studies, our data confirmed the effect of EEB-P on NO generation in J774A.1 cells. The additional data from in vitro study supplied by Tan-No et al. proved that Brazilian propolis extract suppresses corrageenin-induced paw edema in mouse through inhibition of NO production [47].

Macrophages are a major source of many cytokines involved in immune response, hematopoiesis, inflammation, and other homeostatic processes. Upon stimulation by microorganisms, microbial products (e.g., LPS) or endogenous factors (including cytokines), macrophages synthetize de novo, and release a large variety of cytokines: IL-1, IL-3, IL-4, IL-5, IL-6, IL-8, IL-9, IL-10, IL-12, IL-13, IL-17, TNF$\alpha$, IFN- $\alpha$, IFN- $\gamma$, TGF- $\beta$, M-CSF, G-CSF, GM-CSF, MCP-1, MCP-3, MCP-5, MIP-1, MIP-2, RANTES, MIF, and KC. In 


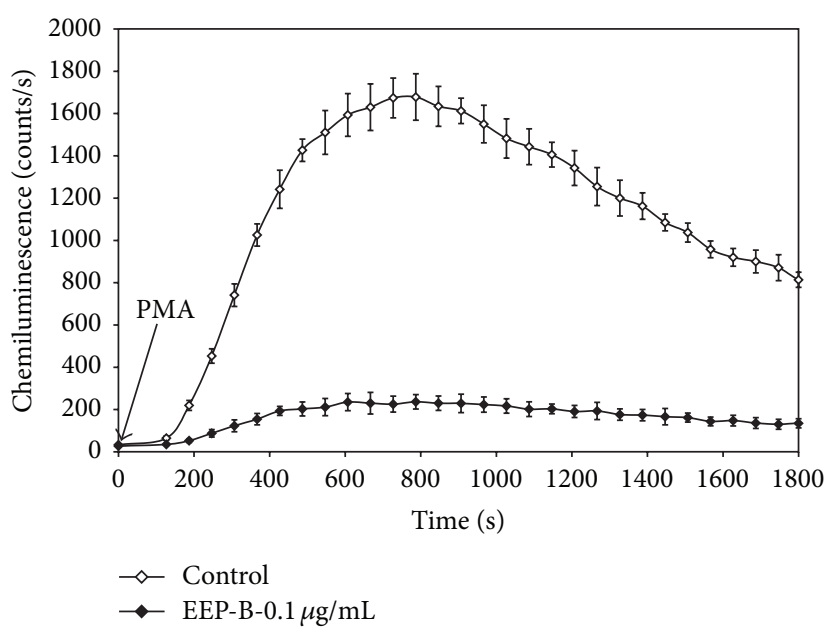

(a)

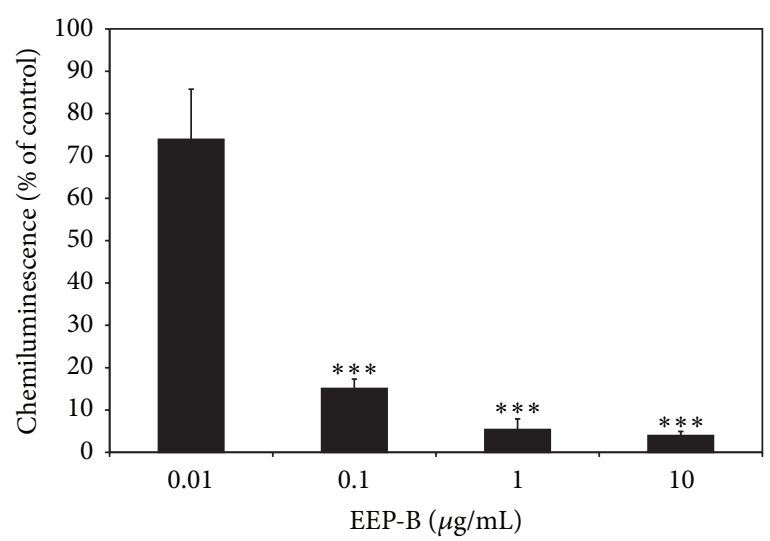

(b)

Figure 6: Effect of EEP-B on chemiluminescence of PMA activated J774A.1 macrophages: (a) time course of chemiluminescence; (b) chemiluminescence of PMA activated J774A.1 macrophages treated with $0.01-10 \mu \mathrm{g} / \mathrm{mL}$ EEP-B for 30 min. Chemiluminescence was determined using microplate luminometer and expressed as a percentage of the PMA-stimulated cells. The values represent mean \pm SD of four independent experiments $(n=8)^{* * *}=P<0.001$ compared to PMA-stimulated cells.



FIGURE 7: Effect of EEP-B on nitrite (NO) production in LPS + IFN$\gamma$ stimulated J774A.1 macrophages. J774A.1 cells were incubated with $5-50 \mu \mathrm{g} / \mathrm{mL}$ EEP-B and/or LPS + IFN- $\gamma$ for $24 \mathrm{~h}$. NO production was measured by the Griess reaction assay and expressed as a percentage of LPS + IFN- $\gamma$-stimulated cells. The values represent mean \pm SD of three independent experiments $(n=12)^{* * *}=P<0.001$ compared to LPS + IFN- $\gamma$-stimulated cells.

addition, these cytokines can modulate most of the functions of macrophages, cell surface markers expression, and others cytokines secretion. The cytokine network plays a key role in regulation of macrophages activation [48]. To gain further insight into anti-inflammatory activity of EEP-B, nineteen cytokines secreted by macrophages were analyzed. We investigated the influence of Brazilian green propolis extract on production of cytokine IL-1 $\alpha$, IL-1 $\beta$, IL-3, IL-4, IL-5, IL-6, IL9, IL-10, IL-12p40, IL-13, IL-17, TNF- $\alpha$, IFN- $\gamma$, G-CSF, GMCSF, MCP-1, MIP- $1 \alpha$, MIP-1 $\beta$, and RANTES in LPS + IFN- $\gamma$ stimulated macrophages. Inflammatory cytokines are generated by innate immune cells during infection. For example, LPS induces strong release of IL-1, IL-6, IL-12, and TNF- $\alpha$ by the macrophages $[37,48,49]$. The upregulation of these inflammatory cytokines in LPS or LPS + IFN- $\gamma$ activated macrophages was blocked by propolis extracts. We showed that EEP-B significantly downregulated the production of IL-1 $\alpha$, IL-1 $\beta$, IL-6, IL-12p 40, and TNF- $\alpha$ in LPS + IFN- $\gamma$ treated J774A.1 cells. Bachiega et al. described the increase of IL-1 $\beta$ and decrease of IL- 6 production by Brazilian green propolis extract and its phenolic acids in peritoneal murine macrophages challenged with LPS [50]. Shi et al. and Wang et al. noticed that extracts from Chinese propolis suppress mRNA and protein expression of IL-1 $\beta$ and IL- 6 induced by LPS in RAW264.7 cells [51, 52]. Blonska et al. reported the inhibition of IL- $1 \beta$ mRNA and protein expression in LPSstimulated J774A.1 macrophages by extract of Polish propolis and its flavones [27]. We observed that the secretion of interleukin IL-4 and IL-13 in LPS + IFN- $\gamma$ activated J774A.1 cells was also reduced by EEP-B. Whereas the concentrations of IL-3, IL-5, IL-9, IL-10, IL-17, and IFN- $\gamma$ were only slightly or not at all affected after incubation with EEP-B. The in vivo experiment performed by Franchin et al. showed down-regulation of IL- $1 \beta$ and TNF- $\alpha$ production by extract of geopropolis from Melipona scutellaria [53]. By contrast, Orsatti et al. demonstrated upregulation of IL- $1 \beta$ and IL- 6 in in vivo model [54]. In other in vivo test $\mathrm{Hu}$ et al. found out that Chinese propolis extracts suppressed carrageenan induced peritonitis and pleurisy or acute lung damage in rats through decrease of the number of neutrophils. Chinese propolis also down-regulated IL- 6 in Freund's complete adjuvant (FCA) induced arthritis in rats [55]. Paulino et al. reported a significant inhibition of paw edema in carrageenan induced model of murine peritonitis by artepillin $\mathrm{C}$ also via decrease of neutrophils' percentage in the peritoneal cavity [46].

The colony-stimulating factors, G-CSF, and GM-CSF release in activated J774A.1 macrophages were decreased by EEP-B. Chemokines (MCP-1, MCP-3, MIP-1, MIP-2, 




(a)



(c)



(e)



(g)

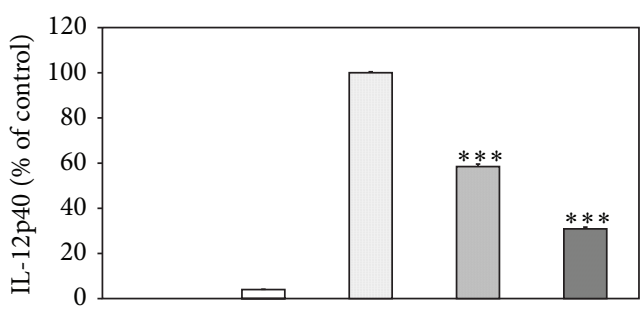

(i)



(k)

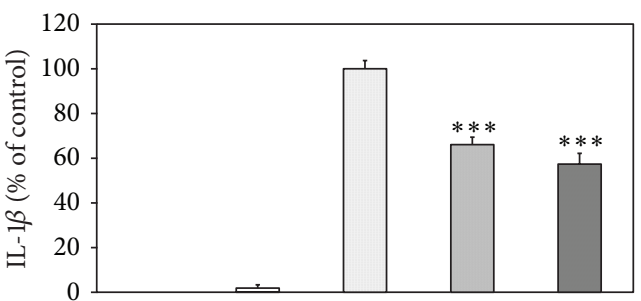

(b)



(d)

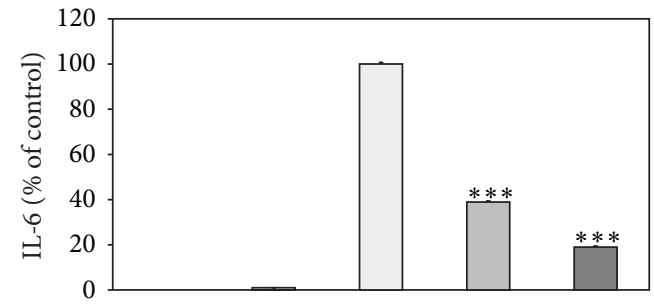

(f)

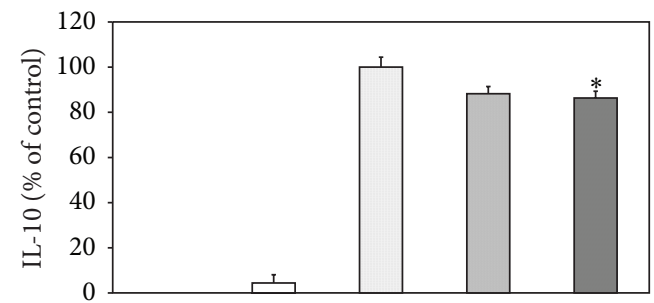

(h)



(j)



(l)

FIgUre 8: Continued. 


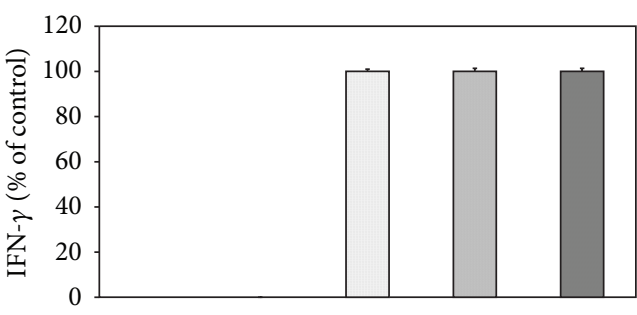

(m)

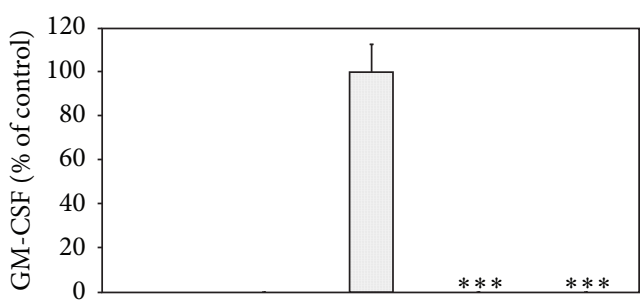

(o)

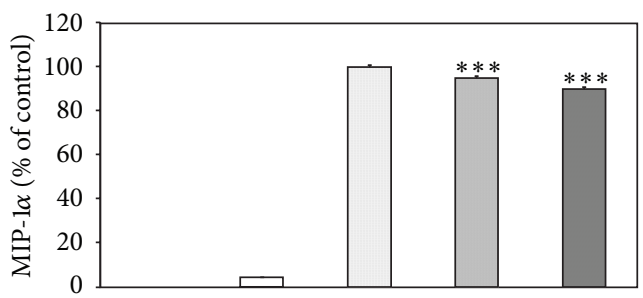

(q)

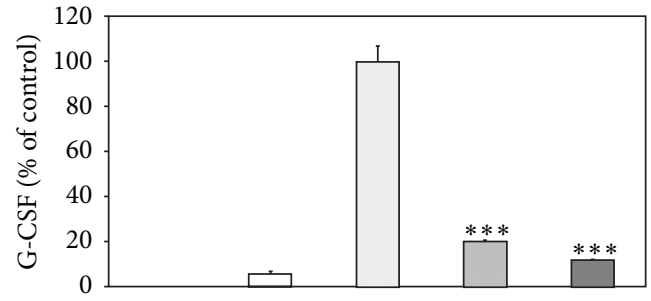

(n)

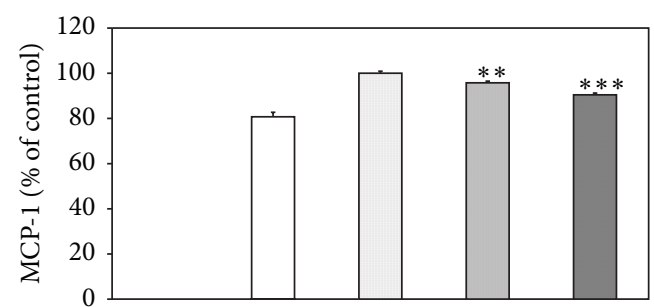

(p)

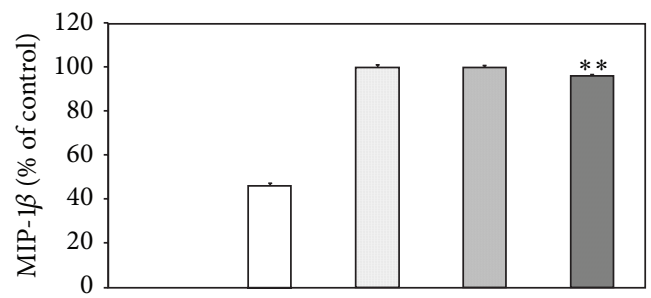

(r)

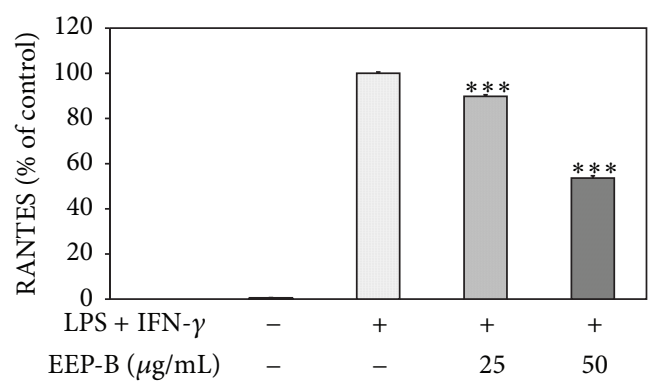

(s)

Figure 8: Effect of EEP-B on cytokines production in LPS + IFN- $\gamma$ stimulated J774A.1 macrophages: (a) IL-1 $\alpha$, (b) IL-1 $\beta$, (c) IL-3, (d) IL-4, (e) IL-5, (f) IL-6, (g) IL-9, (h) IL-10, (i) IL-12p40, (j) IL-13, (k) IL-17, (l) TNF- $\alpha$, (m) IFN- $\gamma$, (n) G-CSF, (o) GM-CSF, (p) MCP-1, (q) MIP-1 $\alpha$, (r) MIP-1 $\beta$, and (s) RANTES. J774A.1 cells were incubated with $25-50 \mu \mathrm{g} / \mathrm{mL}$ EEP-B and/or LPS + IFN- $\gamma$ for 24 h. Cytokine concentrations in the culture medium were determined by Multiplex (19-plex) bead-based cytokine assay. The values represent mean \pm SD of two independent experiments $(n=8){ }^{*}=P<0.05,{ }^{* *}=P<0.01,{ }^{* * *}=P<0.001$ compared to LPS + IFN- $\gamma$-stimulated cells.

and RANTES) are chemotactic cytokines contributing to the recruitment of circulating monocytes within tissues. Our study extended to macrophage chemokines demonstrated that EEP-B downregulates the expression of MCP-1, MIP- $1 \alpha$, MIP- $1 \beta$, and RANTES in LPS + IFN- $\gamma$ stimulated J774A.1 cells. These results suggest a crucial contribution of Brazilian green propolis in the modulation of chemokine-mediated inflammation.

The findings confirm significant anti-inflammatory effect of ethanolic extract of Brazilian green propolis on macrophage in vitro model.

\section{Conclusion}

Propolis has become a subject of special interest as a source of valuable phenolic compounds to developed food components, dietary supplements, or even pharmaceuticals for the prevention or treatment of inflammatory diseases. Artepillin C, drupanin, baccarin, $p$-coumaric acid, and kaempferide are the main ingredients of Brazilian green propolis. Our recent study provide new evidence-based proofs of anti-inflammatory properties of Brazilian green propolis extract. 


\section{Conflict of Interests}

No conflict of interests was declared in relation to this paper.

\section{Acknowledgments}

This work was supported by a Research Grant KNW-1063/P/2/0 from the Medical University of Silesia in Katowice (Poland). The authors thank Mr. Rindai Yamamoto, the President of Nihon Natural Foods Co., Ltd. (Tokyo, Japan), and Mrs. Etsuko Yamamoto, the President of Komyodo Kampo Shoyaku Co., Ltd. (Tokyo, Japan), for the sample of Brazilian green propolis.

\section{References}

[1] Y. K. Park, S. M. Alencar, and C. L. Aguiar, "Botanical origin and chemical composition of Brazilian propolis," Journal of Agricultural and Food Chemistry, vol. 50, pp. 2502-2506, 2002.

[2] F. C. Lopes, V. Bankova, and J. M. Sforcin, "Effect of three vegetal sources of propolis on macrophages activation," Phytomedicine, vol. 10, no. 4, p. 343, 2003.

[3] J. M. Sforcin, "Propolis and the immune system: a review," Journal of Ethnopharmacology, vol. 113, pp. 1-14, 2007.

[4] E. W. Teixeira, D. Message, G. Negri, A. Salatino, and P. C. Stringheta, "Seasonal variation, chemical composition and antioxidant activity of brazilian propolis samples," EvidenceBased Complementary and Alternative Medicine, vol. 7, no. 3, pp. 307-315, 2010.

[5] J. M. Sforcin and V. Bankova, "Propolis: is there a potential for the development of new drugs?" Journal of Ethnopharmacology, vol. 133, no. 2, pp. 253-260, 2011.

[6] E. Szliszka, G. Zydowicz, B. Janoszka, C. Dobosz, G. KowalczykZiomek, and W. Król, "Ethanolic extract of Brazilian green propolis sensitizes prostate cancer cells to TRAIL-induced apoptosis," International Journal of Oncology, vol. 38, no. 4, pp. 941-953, 2011.

[7] D. Sawicka, H. Car, M. H. Borawska, and J. Niklinski, "The anticancer activity of propolis," Folia Histochemica et Cytobiologica, vol. 50, pp. 25-37, 2012.

[8] G. C. Franchi, C. S. Moraes, V. C. Toreti, A. Daugsch, A. E. Nowill, and Y. K. Park, "Comparison of effects of the ethanolic extracts of Brazilian propolis on human leukemic cells as assessed with the MTT assay," Evidence-Based Complementary and Alternative Medicine, vol. 2012, Article ID 918956, 6 pages, 2012.

[9] E. Szliszka and W. Król, "Polyphenols isolated from propolis augment TRAIL-induced apoptosis in cancer cells," EvidenceBased Complementary and Alternative Medicine, vol. 2013, Article ID 731940, 10 pages, 2013.

[10] A. H. Banskota, Y. Tezuka, and S. Kadota, "Recent progress in pharmacological research of propolis," Phytotherapy Research, vol. 15, no. 7, pp. 561-571, 2001.

[11] E. Szliszka, Z. P. Czuba, M. Domino, B. Mazur, G. Zydowicz, and W. Król, "Ethanolic extract of propolis (EEP) enhances the apoptosis-inducing potential of TRAIL in cancer cells," Molecules, vol. 14, no. 2, pp. 738-754, 2009.

[12] E. Szliszka, Z. P. Czuba, J. Bronikowska, A. Mertas, A. Paradysz, and W. Król, "Ethanolic extract of propolis (EEP) augments TRAIL-induced apoptotic death in prostate cancer cells,"
Evidence-Based Complementary and Alternative Medicine, vol. 2011, Article ID 535172, 11 pages, 2011.

[13] G. C. Chan, K. W. Cheung, and D. M. Sze, "The immunomodulatory and anticancer properties of propolis," Clinical Reviews in Allergy \& Immunology, vol. 44, no. 3, pp. 262-273, 2013.

[14] D. L. Laskin and K. J. Pendino, "Macrophages and inflammatory mediators in tissue injury," Annual Review of Pharmacology and Toxicology, vol. 35, pp. 655-677, 1995.

[15] A. Aderem and D. M. Underhill, "Mechanisms of phagocytosis in macrophages," Annual Review of Immunology, vol. 17, pp. 593-623, 1999.

[16] W. Król, Z. P. Czuba, G. Pietsz, M. D. Threadgill, and B. D. Cunningham, "Modulation of the cytotoxic activity of murine macrophages by flavones," Current Topics in Biophysics, vol. 20, pp. 88-93, 1996.

[17] M. R. Ahn, K. Kunimasa, S. Kumazawa et al., "Correlation between antiangiogenic activity and antioxidant activity of various components from propolis," Molecular Nutrition and Food Research, vol. 53, no. 5, pp. 643-651, 2009.

[18] L. M. C. Simões, L. E. Gregório, A. A. Da Silva Filho et al., "Effect of Brazilian green propolis on the production of reactive oxygen species by stimulated neutrophils," Journal of Ethnopharmacology, vol. 94, no. 1, pp. 59-65, 2004.

[19] A. A. Carvalho, D. Finger, C. S. Machado et al., "In vivo antitumoural activity and composition of an oil extract of Brazilian propolis," Food Chemistry, vol. 126, pp. 1239-1245, 2011.

[20] S. A. Moura, G. Negri, A. Salatino et al., "Aqueous extract of Brazilian green propolis: primary components, evaluation of inflammation and wound healing by using subcutaneous implanted sponges," Evidence-Based Complementary and Alternative Medicine, vol. 2011, Article ID 748283, 8 pages, 2011.

[21] F. Pellati, G. Orlandini, D. Pinetti, and S. Benvenuti, "HPLCDAD and HPLC-ESI-MS/MS methods for metabolite profiling of propolis extracts," Journal of Pharmaceutical and Biomedical Analysis, vol. 55, no. 5, pp. 934-948, 2011.

[22] S. I. Falcao, N. Vale, and P. Gomes, "Phenolic profiling of Portuguese propolis by LC-MS spectrometry: uncommon propolis rich in flavonoid glycosides," Phytochemical Analysis, 2012.

[23] C. C. Fernandes-Silva, A. Salatino, M. L. Salatino, E. D. Breyer, and G. Negri, "Chemical profiling of six samples of Brazilian propolis," Quimica Nova, vol. 36, pp. 237-240, 2013.

[24] A. C. H. F. Sawaya, D. M. Tomazela, I. B. S. Cunha et al., "Electrospray ionization mass spectrometry fingerprinting of propolis," Analyst, vol. 129, no. 8, pp. 739-744, 2004.

[25] D. Wojnicz, A. Z. Kucharska, A. Sokół-Łętowska, M. Kicia, and D. Tichaczek-Goska, "Medicinal plants extracts affect virulence factors expression and biofilm formation by the uropathogenic Escherichia coli," Urological Research, vol. 40, pp. 683-697, 2012.

[26] S. Keckes, U. Gasic, T. Cirkovic-Velickovic, D. MilojkovicOpsenica, M. Natic, and Z. Tesic, "The determination of phenolic profiles of Serbian unifloral honeys using ultra-highperformance liquid chromatography/high resolution accurate mass spectrometry," Food Chemistry, vol. 138, pp. 32-40, 2013.

[27] M. Blonska, J. Bronikowska, G. Pietsz, Z. P. Czuba, S. Scheller, and W. Król, "Effects of ethanol extract of propolis (EEP) and its flavones on inducible gene expression in J774A.1 macrophages," Journal of Ethnopharmacology, vol. 91, no. 1, pp. 25-30, 2004.

[28] E. Szliszka, Z. P. Czuba, Ł. Sędek, A. Paradysz, and W. Król, "Enhanced TRAIL-mediated apoptosis in prostate cancer cells by the bioactive compounds neobavaisoflavone and psoralidin 
isolated from Psoralea corylifolia," Pharmacological Reports, vol. 63, no. 1, pp. 139-148, 2011.

[29] E. Szliszka, D. Jaworska, M. Kłósek, Z. P. Czuba, and W. Król, "Targeting death receptor TRAIL-R2 by chalcones for TRAILinduced apoptosis in cancer cells," International Journal of Molecular Sciences, vol. 13, pp. 15343-15359, 2012.

[30] E. Szliszka, K. J. Helewski, E. Mizgala, and W. Król, “The dietary flavonol fisetin enhances the apoptosis-inducing potential of TRAIL in prostate cancer cells," International Journal of Oncology, vol. 39, no. 4, pp. 771-779, 2011.

[31] E. Szliszka, E. Kostrzewa-Susłow, J. Bronikowska et al., "Synthetic flavanones augment the anticancer effect of tumor necrosis factor-related apoptosis-inducing ligand (TRAIL)," Molecules, vol. 17, pp. 11693-11711, 2012.

[32] I. C. Jang, E. K. Jo, M. S. Bae et al., "Antioxidant and antigenotoxic activities of different parts of persimmon (Diospyros kaki cv. Fuyu) fruit," Journal of Medicinal Plant Research, vol. 4, no. 2, pp. 155-160, 2010.

[33] E. Szliszka, D. Skaba, Z. P. Czuba, and W. Król, "Inhibition of inflammatory mediators by neobavaisoflavone in activated RAW264.7 macrophages," Molecules, vol. 16, pp. 3701-3712, 2011.

[34] W. Król, Z. P. Czuba, M. D. Threadgill, B. D. M. Cunningham, and G. Pietsz, "Inhibition of nitric oxide (NO.) production in murine macrophages by flavones," Biochemical Pharmacology, vol. 50, no. 7, pp. 1031-1035, 1995.

[35] S. B. Yoon, Y. J. Lee, S. K. Park et al., "Anti-inflammatory effects of Scutellaria baicalensis water extract on LPS-activated RAW 264.7 macrophages," Journal of Ethnopharmacology, vol. 125, no. 2, pp. 286-290, 2009.

[36] E. Szliszka, G. Zydowicz, E. Mizgala, and W. Król, "Artepillin C (3,5-diprenyl-4-hydroxycinnamic acid) sensitizes prostate cancer LNCaP cells to TRAIL-induced apoptosis," International Journal of Oncology, vol. 41, pp. 818-828, 2012.

[37] Y. K. Park, J. F. Paredes-Guzman, C. L. Aguiar, S. M. Alencar, and F. Y. Fujiwara, "Chemical constituents in Baccharis dracunculifolia as the main botanical origin of Southeastern Brazilian propolis," Journal of Agricultural and Food Chemistry, vol. 52, no. 5, pp. 1100-1103, 2004.

[38] A. H. Banskota, Y. Tezuka, J. K. Prasain, K. Matsushige, I. Saiki, and S. Kadota, "Chemical constituents of Brazilian propolis and their cytotoxic activities," Journal of Natural Products, vol. 61, no. 7, pp. 896-900, 1998.

[39] W. Król, S. Scheller, Z. Czuba et al., "Inhibition of neutrophils' chemiluminescence by ethanol extract of propolis (EEP) and its phenolic components," Journal of Ethnopharmacology, vol. 55, no. 1, pp. 19-25, 1996.

[40] L. M. C. Simões-Ambrosio, L. E. Gregório, J. P. B. Sousa et al., "The role of seasonality on the inhibitory effect of Brazilian green propolis on the oxidative metabolism of neutrophils," Fitoterapia, vol. 81, no. 8, pp. 1102-1108, 2010.

[41] M. J. V. Fonseca, Y. M. Fonseca, F. Marquele-Oliveira et al., "Evaluation of the potential of Brazilian propolis against UVinduced oxidative stress," Evidence-Based Complementary and Alternative Medicine, vol. 2011, Article ID 863917, 2011.

[42] H. Izuta, Y. Narahara, M. Shimazawa, S. Mishima, S. I. Kondo, and H. Hara, "1,1-diphenyl-2-picrylhydrazyl radical scavenging activity of bee products and their constituents determined by ESR," Biological and Pharmaceutical Bulletin, vol. 32, no. 12, pp. 1947-1951, 2009.

[43] K. Hayashi, S. Komura, N. Isaji, N. Ohishi, and K. Yagi, "Isolation of antioxidative compounds from Brazilian propolis: 3,4-dihydroxy-5-prenylcinnamic acid, a novel potent antioxidant," Chemical and Pharmaceutical Bulletin, vol. 47, no. 11, pp. 1521-1524, 1999.

[44] J. MacMacking, Q. Xie, and C. Nathan, "Nitric oxide and macrophages function," Annual Review of Immunology, vol. 15, pp. 323-350, 1997.

[45] Y. S. Song, E. H. Park, G. M. Hur, Y. S. Ryu, Y. M. Kim, and C. Jin, "Ethanol extract of propolis inhibits nitric oxide synthase gene expression and enzyme activity," Journal of Ethnopharmacology, vol. 80, no. 2-3, pp. 155-161, 2002.

[46] N. Paulino, S. R. L. Abreu, Y. Uto et al., "Anti-inflammatory effects of a bioavailable compound, Artepillin C, in Brazilian propolis," European Journal of Pharmacology, vol. 587, no. 1-3, pp. 296-301, 2008.

[47] K. Tan-No, T. Nakajima, T. Shoji et al., "Anti-inflammatory effect of propolis through inhibition of nitric oxide production on carrageenin-induced mouse paw edema," Biological and Pharmaceutical Bulletin, vol. 29, no. 1, pp. 96-99, 2006.

[48] J. M. Cavaillon, "Cytokines and macrophages," Biomedicine and Pharmacotherapy, vol. 48, pp. 445-453, 1994.

[49] T. Hanada and A. Yoshimura, "Regulation of cytokine signaling and inflammation," Cytokine and Growth Factor Reviews, vol.13, no. 4-5, pp. 413-421, 2002.

[50] T. F. Bachiega, C. L. Orsatti, A. C. Pagliarone, and J. M. Sforcin, "The effects of propolis and its isolated compounds on cytokine production by murine macrophages," Phytotherapy Research, vol. 26, pp. 1308-1313, 2012.

[51] H. Shi, H. Yang, X. Zhang, and L. Yu, "Identification and quantification of phytochemical composition and anti-inflammatory and radical scavenging properties of methanolic extract of Chinese propolis," Journal of Agricultural and Food Chemistry, vol. 60, pp. 12403-12410, 2012.

[52] K. Wang, S. Ping, S. Huang et al., "Molecular mechanisms underlying the in vitro anti-inflammatory effects of flavonoidrich ethanol extract from Chinese propolis," Evidence-Based Complementary and Alternative Medicine, vol. 2013, Article ID 127672, 11 pages, 2013.

[53] M. Franchin, M. G. Cunha, C. Denny et al., "Geopropolis from Melipona scutellaris decreases the mechanical inflammatory hypernociception by inhibiting the production of IL- $1 \beta$ and TNF- $\alpha$," Journal of Ethnopharmacology, vol. 143, pp. 709-715, 2012.

[54] C. L. Orsatti, F. Missima, A. C. Pagliarone et al., "Propolis immunomodulatory action in vivo on toll-like receptors 2 and 4 expression and on pro-inflammatory cytokines production in mice," Phytotherapy Research, vol. 24, no. 8, pp. 1141-1146, 2010.

[55] F. Hu, H. R. Hepburn, Y. Li, M. Chen, S. E. Radloff, and S. Daya, "Effects of ethanol and water extracts of propolis (bee glue) on acute inflammatory animal models," Journal of Ethnopharmacology, vol. 100, no. 3, pp. 276-283, 2005. 


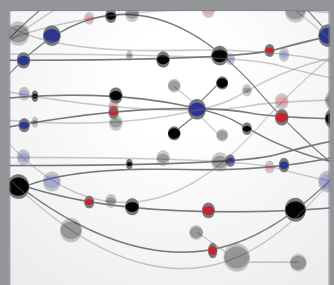

The Scientific World Journal




Gastroenterology

Research and Practice
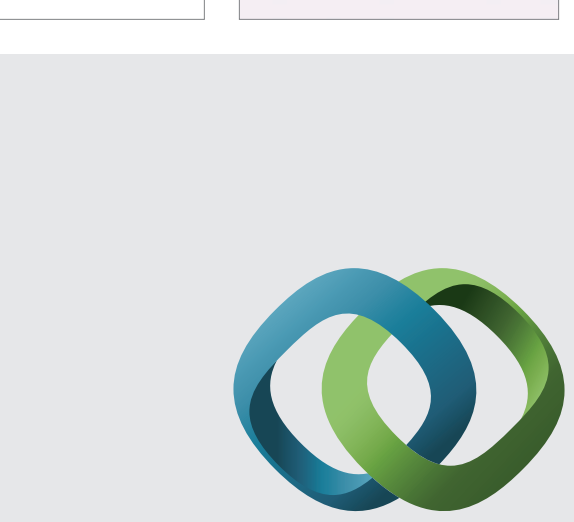

\section{Hindawi}

Submit your manuscripts at

http://www.hindawi.com

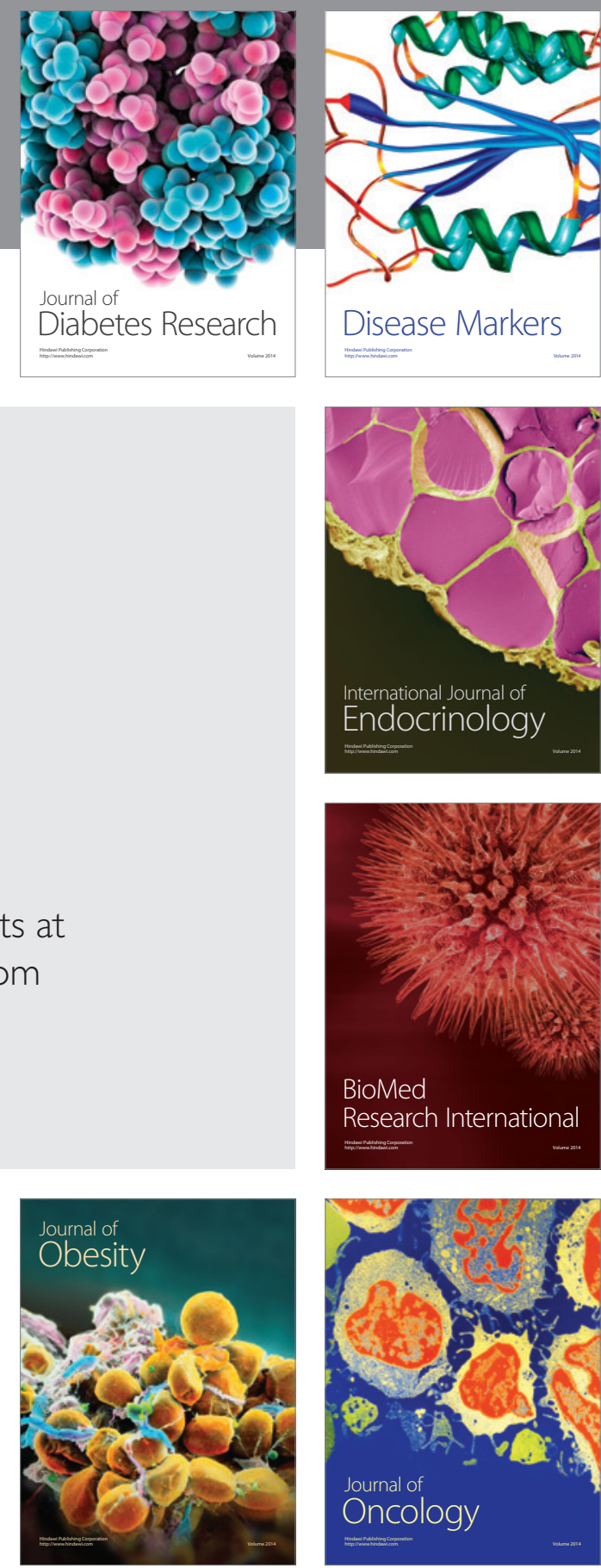

Disease Markers
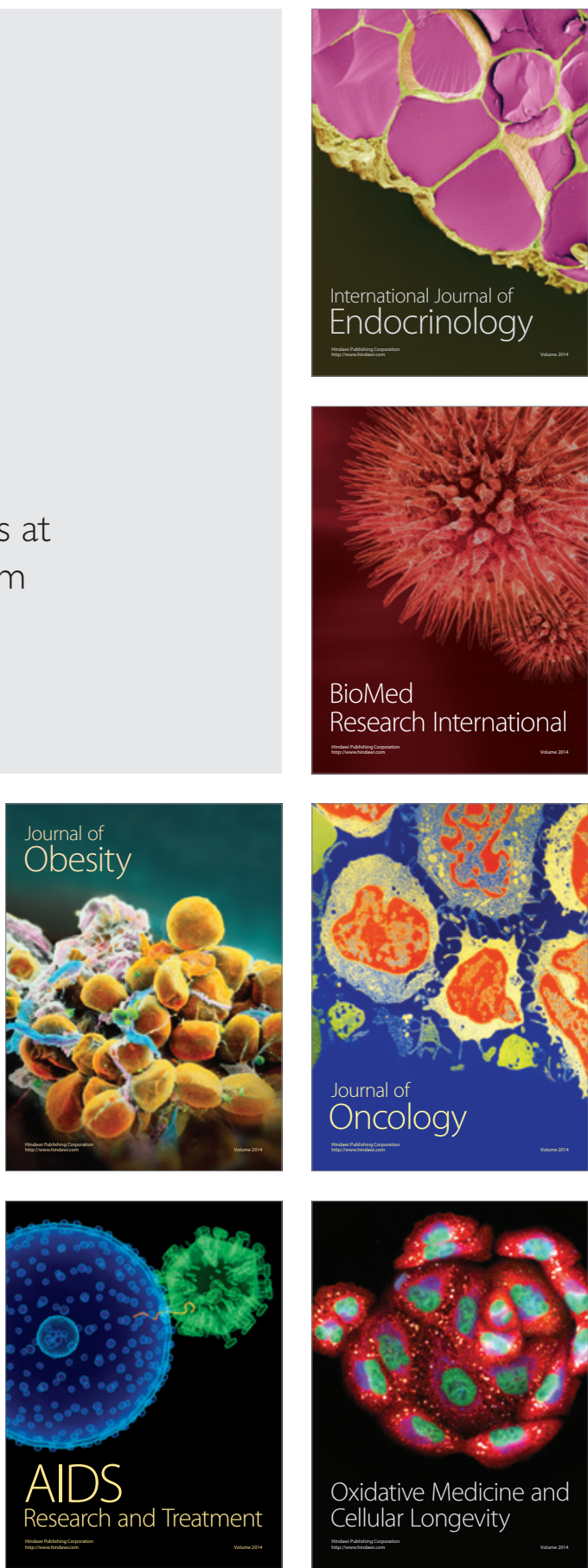